STUDII

\title{
ALTERNATIVE POSSIBILITIES OF LEGAL PROTECTION AND ENFORCING CLAIMS IN THE AREA OF HEALTHCARE SERVICES IN HUNGARY ${ }^{1}$
}

\author{
DOI:10.24193/SUBBiur.63(2018).2.1 \\ Published Online: 2018-06-29 \\ Published Print: 2018-06-29
}

\section{J udit ZÁKÁNY*}

\begin{abstract}
The aim of our paper is the problem-orientated examination of the alternative procedures of handling conflicts, in Hungary, in cases of harms in connection with healthcare services. We shall see that those alternative procedures differ from the traditional legal procedures of enforcing a claim. First, we will examine the reason for dealing with the alternative possibilities of legal protection and enforcing a claim (1). Secondly, we will discuss the alternative possibilities of handling conflicts (2): the role of the representative of rights of patients, the complaints towards the healthcare institution and the conservator, the complaint to the healthcare administrative agency and the role of Office of the Commissioner for Fundamental Rights

Last but not least, we will examine the alternative compensation ways (3): the process of the mediator and the process of the conciliator body. Are the alternative possibilities of legal protection useful? Do they represent practical ways to solve the conflicts with healthcare services? These are some of the questions that we try to answer.
\end{abstract}

Keywords: alternative possibilities of legal protection and enforcing of claims, rights of patients, healthcare complaints, healthcare administrative agency.

\section{Introduction. The significance of alternative possibilities of legal protection}

The aim of our paper is the problem-orientated examination of the alternative procedures of handling conflicts - which differ from the traditional legal procedures of enforcing a claim - in Hungary which are available for 
J udit ZÁKÁNY, ALTERNATIVE POSSIBILITIES OF LEGAL PROTECTION

AND ENFORCING CLAIMS IN THE AREA OF HEALTHCARE SERVICES IN HUNGARY

the citizens in cases of harms in connection with healthcare services. Besides the descriptive, analytical method, we have applied the empirical research during the creation of this paper. We have consulted with representative, the Office of the Commissioner for Fundamental Rights, the president of the Conciliator Body of Hajdú-Bihar County, and - in the interest of the examination - we have examined institutional regulations of handling complaints. In addition to the review of the Hungarian system, we demonstrate some foreign legal institutions, drawing a parallel with the Hungarian regulation, or show them as precedents.

First, we will examine the reason for dealing with the alternative possibilities of legal protection and enforcing the claim. There are many adverse effects of the litigation. We mention, for example, litigation means a huge burden for all parties both financially and emotionally, and it takes a much longer time than an alternative way of handling conflicts. In many cases, it intensifies the conflict between the parties, but their cooperation is essential, so the functional relationship is necessary. The consequence, so the possible compensation consists of only one element, the one that is the subject of the claim of the injured party. ${ }^{2}$

The healing action needs peaceful conditions and trust and the action - if it is exaggerated - conduce to an adverse effect and creates the phenomenon of the defensive medicinal activity. Defensive medicine means a substantial financial element and the patient is stressed as well. Another malevolent effect that the constant exterior threat as opposed to discovering the problems weakens theinternal control of themedical society and creates the phenomenon of the honour of the uniform'.

The examination of the possible alternatives is essential furthermore because there is an international trend to avoid the litigation, to popularize the process of the mediator and other alternative instruments of legal protection, and to create new instruments which have broader authority. In the Scandinavian countries, and New Zealand, the liability system is based on the division from litigation. In our opinion, alternative institutions are the future. The examples from abroad prove this.

The undermentioned research proves theimportance of thealternative instruments of legal protection, and its central question is why the patients 
J Udit ZÁKÁNY, ALTERNATIVE POSSIBILITIES OF LEGAL PROTECTION AND ENFORCING CLAIMS INTHE AREA OF HEALTHCARE SERVICES IN HUNGARY

sue the healthcare providers? If we look back till this point, during the examination of the problems we can see the ways that lawsuits can be averted 3 , avoided 4 , and which expectations the tools, institutions of handling conflicts must measure up to, and that the alternative possibilities of legal protection would measure up to these expectations.

Researches from many countries - like England, the United States of America and Hungary ${ }^{5}$ - will be demonstrated, the researches had been made with sociological and psychological methods. The results are the following ones.

Theinformation of thepatient is thekey. Namely, thereis acommunication problem in every case under dispute. According to the researches, most of the patients are displeased with the way that the doctors have informed them about their illness, the treatments, the possible causes of the faults. Moreover, in connection with the communication, they often complain about theapathy of the doctors, thelack of empathy, the lack of care about the patient's personality, comfort. 6

The most important lessons of the researches are the four main causes in the malpractice actions. The patients mentioned the causes in the following order by their importance:

One of the causes that the patients are displeased with the standards of the healthcare supplies, and they think that if their cases become public, they would prevent similar cases. We suppose that for the sake of this cause, an examination by an authority or theinstitution of the Ombudsman is perfectly convenient.

The second motive stressed by the patients is that the communication is not adequate towards them, they feel that doctors do not show solidarity, they do not communicate in the right tone ${ }^{7}$. If the patient feels that they have not been thoughtful enough in connection with his problem, litigation is understandable because of his injury. Another problem is they do not know that there was negligence or an unavoidable result due to their lack of specialised knowledge. So they want the process to be examined to know what has happened. An efficiently working institutional tool of handling the conflicts or the process of the conciliator body would be a proper solution.

Another motivation that the injured patients want to get compensation, but the compensation is not the first aim for most of the patients ${ }^{8}$. This is 
J udit ZÁKÁNY, ALTERNATIVE POSSIBILITIES OF LEGAL PROTECTION

AND ENFORCING CLAIMS IN THE AREA OF HEALTHCARE SERVICES IN HUNGARY

entirely understandable, but wecan say that it does not necessarilyneed litigation. A settlement made during the process of a mediator or an examination by a specific administrative board can give this compensation too, eliminating the disadvantages of the classic ways of enforcing the claim.

Because of that, not only the legal proceedings are useful - which can assure the compensation for the injured party - but those procedures are too, which cannot assure the compensation, but by examination, they can give answers and obligate the institutions in towards changes.

Finally, the injured patients have mentioned that they want to know who was liable for their damages and want this person to take responsibility for that. Most patients say that if they had cared for them, explained the circumstances of the events, took the responsibility and apologised, they would not have sued. In many cases, the claim of the institution of action is born because the healthcare institution does not deal with the patient's problem, or not in an appropriate way, and the injured party has no other possibilities ${ }^{9}$. They mentioned that if the liable ones have paid for them without litigation, they would not have sued. 10

The concluding lesson of the research is that the alternative possibilities of legal protection are useful and practical ways to solve the conflicts with the healthcare services. With them, the aims of theinjured patients and their relatives are much available.

The alternative possibilities of debate settlement are in two groups in this paper. ${ }^{11}$ I examine the classic alternative possibilities of debate settlement, so the process of the healthcare mediator and the conciliator body. With these, the compensation is available too, so these are alternative possibilities for compensation. Besides, we examine the alternative possibilities of handling conflicts, so the institutions which ensure possibilities of plaint and examination. Usually, these do not end with compensation for the complaint, the aim is to discover the facts, the cause of the problem, and to conclude the lesson and to avoid the similar cases.

\section{Alternative possibilities of handling conflicts 2.1 Representative of rights of patients}

The birth of the representative of rights of patients is connected with the entry into force of the CLIV Act of 1997 (Health Act) which contains the patients' rights ${ }^{12}$ - these have high importance level in Europe - breaking 
J Udit ZÁKÁNY, ALTERNATIVE POSSIBILITIES OF LEGAL PROTECTION AND ENFORCING CLAIMS INTHE AREA OF HEALTHCARE SERVICES IN HUNGARY

with the paternal view of the prior Health Act. In favour of following the observing of the rights from the new act, the representatives of rights of patients have begun to work in many healthcare institutions after the entry into force of the Health Act - without legal obligation - and the hospitals have been employed them ${ }^{13}$.

On the 1st of J anuary 2000, theindependent system of representatives of rights of patients was born ${ }^{14}$. First, this means personal independence, because the representative cannot be employed by an institution and be the representative in it at the same time ${ }^{15}$. Secondly, this means institutional autonomy, so the representative is employed by an institution - defined in the Act - as the Integrated Legal Protection Service ${ }^{16}$. We believe that this independence should be notorious and be pronounced in favour of the trust towards the representatives.

The base of the activity of the representatives is that the patients visit them with their problems. The consultation and the connection are essential parts of their process ${ }^{17}$. There is a legal obligation for healthcare institutions to insert the name, the availability and the time of the consulting hours of the representative ${ }^{18}$. There are many goals and effects of the consultation with the representative. In some cases, people ask for information in connection with their rights and possibilities of due process, or they make observations in connection with the services, or they complain.

If the patient does not want to ask only for information, but he wants to complain or report a problem, the representative helps to access to the healthcare documents and to ask questions and make perceptions ${ }^{19}$; he gives a helping hand to handle the complaints in many ways, he listens to the claims, and offers the most competent forum to the patient. The most important task of the representative is to solve the conflicts, the problems on a local level, therefore on the lowest one ${ }^{20}$. Their mission is - according to the law - to urge the injured people to use the out of court possibilities. For example, to use the possibility of conciliation between the patient and the institution, making an agreement, turning to the representative, send the complaints to the institution instead of suing.

If the injured party wants to complain, the representative helps with it. He helps to word the complaints, or he can make a claim himself in the name of the patient and represent the patient during the process by written authorisation $^{21}$. 
J Udit ZÁKÁNY, ALTERNATIVE POSSIBILITIES OF LEGAL PROTECTION

AND ENFORCING CLAIMS INTHE AREA OF HEALTHCARE SERVICES IN HUNGARY

It is an important task of the representative to follow the operation of the healthcare institution and - if it is necessary - makes perceptions. If he detects illegal practice, deficiency, he must report this to the head and the conservator of the institution, and he can also suggest the solution at the same time $^{22}$.

The Health Act gives as a task for the representative also to inform regularly the healthcare employees of their rights, and the connected amendments of therules. In our opinion, it would bevital and useful if the healthcareemployees would receivesolid pieces of information, to know well therights and obligations of both parties and the connected amendments.

However, in real life this does not work that way. To work well, we are convinced that more representatives and consulting hours are needed, beside the existing 23 representatives. It is necessary to increase the number of representatives, because the low number is the central factor against the more effective functioning of this legal institution ${ }^{23}$.

Since the formation of the representative system, the most frequent complaints are connected with injuring the same rights. One of these is the injuries of the right for information. There are significantly many disputes which are preceded by harming dignity. In the latter cases, conflicts were born by hindering the patients, the communication with jeer, violating the intimacy or the bias ${ }^{24}$. There are many complaints because of the lack of the sufficient health care services too. In most of these cases, the insufficient health care services are the problem, but there are complaints in connection with the system of the waiting-list, booking, the psychiatric services, or the gratitude-money.

In Austria for instance, there is a similar representative system (PA system) to the Hungarian one. First, it was configured in Carinthia and UpperAustria in 1991 than in 1993, the employment of the representatives became compulsory for every province. Centrally, there are only frame rules, so the representative systems are structurally different in every province, and differ from each other by their authorities and the duties of the PA-s ${ }^{25}$. J ust like their Hungarian colleagues, the Austrian PA-s inform the patients, help with their rights and represent them in any process related to enforcing the patients' rights. 
J udit ZÁKÁNY, ALTERNATIVE POSSIBILITIES OF LEGAL PROTECTION AND ENFORCING CLAIMS IN THE AREA OF HEALTHCARE SERVICES IN HUNGARY

\subsection{The complaints towards the healthcare institution and the conservator}

The Health Act gives the opportunity for the patient to complain to the healthcare supplier in connection with the healthcare service. The institutional complaints settlements - as the name suggests - do not give a chance for examiningirrespectively of the hospital, this works within the hospital, as the first and general opportunity for the injured patients. The existence of an efficient inner control is essential for the institution. Because of this, the case will not be examined outside of theinstitution ${ }^{26}$. The representatives often help in this way, according to the features of the dispute and the will of the patient.

One of the problems is that the law says only that the healthcare service provider and its operator must examine the complaints in connection with the services and they must inform the patient at least in 30 workdays. The law orders the healthcare institutions to create the regulation on the procedural order of handling complaints, but it does not request the same thing from the operator. The consequence of this is that the documents are entirely different, and this is against the efficiency of handling complaints of the institutions.

In many cases, we have encounter regulations which formally do the requirements of the law, but do not give real possibilities for legal remedies, and let full discretionary power to the health institution. In favour of making the institutional handling complaints more efficient, we suggest unifying the proceedings. This unification can be successful with strict rules and with the help of the direction from the Integrated Legal Protection Service, which will determine the frame of the regulations on handling complaints.

Earlier, regulations of handling complaints could be got taped by the centre institution supervised by the Minister of health ${ }^{27}$. We believe that this opportunity must be used again, and must becompulsory, because the revision of the many institutional processes is necessary, and the designation of the competent body is justified too. Every regulation must contain at least the form of the complaints, the place where to hand in them, where to report them, theform to examine the documents, the process of the examination, the elements 
J Udit ZÁKÁNY, ALTERNATIVE POSSIBILITIES OF LEGAL PROTECTION

AND ENFORCING CLAIMS IN THE AREA OF HEALTHCARE SERVICES IN HUNGARY

of the decision, the order of the notification, the fact that the use of the right of the complaints does not mean that the patient cannot turn to other organizations which are contained in other laws. In many cases, these elementary pieces of information do not turn up.

The 1st Subsection of the 29th Section of the Health Act ensures the opportunity for the patient to complain to the conservator of the healthcare supplier in connection with the healthcare service. The examination of the complaints by the conservator is based mostly on the information from the institution. So, while in theory, this is a superior forum than the institution, the examination ends with a similar result to the examination by the health institution.

It can be said that - despite its importance - the complaints, towards the institution and the conservator, usually do not end with the result expected by the patient. The detailed examination usually means an incompetent way, and the complainant gets a short, dismissive order which does not explain or answer anything well. The examination just in some cases ends with the admission of the problems, the apology, the offer for out of court settlement. If it becomes possible that this possibility gives soothing answers and legal remedy in more cases for the patient, the numbers of the excessive, inadequate social and legal reactions would be smaller.

The clinical mediator is a very well-known form of the institutional settling of complaints abroad. In our opinion, this is a very positiveinstitution, which can be used in Hungary too. In the United States of America, there were many experimental programs examining the representative if he - who is employed in the health institutions - can or cannot influence the number of the actions for damages and the extent of the satisfaction of the patients ${ }^{28}$. In these programs, impartial mediators have done the every-day-job in the hospitals, who were adept in handling conflicts and medical work. The most important task of the mediator was to help the communication for example in those hard cases, when there has been complication during the medical interference, or the patient had died, or when the patient has not been satisfied with the result of the treatment, with thelevel of the service, with theinformation and he has deliberated to litigate.

Also, mediators havetaken a hand in the examination of the problematic cases and the faults, and they had to suggest solutions with which the similar 
J udit ZÁKÁNY, ALTERNATIVE POSSIBILITIES OF LEGAL PROTECTION AND ENFORCING CLAIMS IN THE AREA OF HEALTHCARE SERVICES IN HUNGARY

cases would be avoidable. Furthermore, they have taken a hand in the information of the healthcare employers. The programs have ended with unmistakably positive results, the number of the actions for damages against the hospitals has decreased, so the costs in connection with the actions because of malpractice and the number of the public negative cases have decreased, too. The programs have contributed to the identification of the system-errors, to the development of the innovates, the programs have revised the satisfaction of the patients and the healthcare employers. After a year and a half, according to the data of an experimental program in every case when a mediator has participated, the two-tierce of the cases have been solved out of court in 10 hours.

There are similar intentions in many countries of the European Union, for example, in some hospitals of Belgium, France, the Czech Republic, Ireland there are the impartial mediators who are employed by the institution and help immediately in the complicated cases. In other countries, like Estonia and Luxembourg, there are mediators too who help solve the conflicts between the healthcare supplier and the patients, but they are not employees, if it is necessary, the institution makes a contract with them. In Slovenia, the Association of Health Institutions ensures a proper education for the mediators of the hospital and allow them a job to the institutions.

\subsection{Complaint to the healthcare administrative agency}

Acoording to therules of theXI Act of 1991, on the healthcare government and administrative activity - hereafter: Ehi. - the healthcare administrative agency supervises theemergence of therules on the operation of the healthcare institutions and supervises the healthcare suppliers ${ }^{29}$. If it is suspicious that there is the breach of the professional rules, the patient can complain to the healthcare administrative agency - besides theinstitution and the conservator - which can use two different kinds of process.

The aim and the result of one of these is a stand-in connection with the individual complaints of the patients, in the case of a rightful complain the aim and the result is the restoration of the legal status, the remedy of the injury and the necessary actions ${ }^{30}$. This process is based on the CLXV Act of 2013 (hereafter: Complaint Act) ${ }^{31}$. According to the ComplaintAct, anyonecan 
J Udit ZÁKÁNY, ALTERNATIVE POSSIBILITIES OF LEGAL PROTECTION

AND ENFORCING CLAIMS IN THE AREA OF HEALTHCARE SERVICES IN HUNGARY

complain ${ }^{32}$ or tender a public announcement ${ }^{33}$ to the state or the local government agency. This possibility lives in connection with the healthcare services, too. Thus, the complaints and the public announcement can be tendered to the healthcare administrative agency which is authorised to give the operating permit for the healthcare suppliers ${ }^{34}$.

After six months from the harmful activity or the knowledge of the malpractioe, the examination of the complaint can be passed over, the complaints which are tendered over a year are automatically rejected. These rules from the Complaint Act are in many institutional regulations on handling conflicts. The short of the term compared to the litigious possibility is not justified, because it is opposed to the out of court examination and solution. Deciding the dispute, the competent supervisory system - which operates in favour of the professional supervision of the healthcare suppliers - has an important role. The supervisor is in the register of the healthcare employees, has a professional qualification, knowledgeand practice, and theChief Medical Officer registers him and names his speciality 35 . The supervisors examine that the servioes have been - or have not - implemented acoording to the healthcare rules, directives, methodology letters and professional protocols. The examination does not end with an order, but with a notification, so remedy is not possible ${ }^{36}$. If the complaints are grounded, the healthcare institution must ensure the restoration of the legal status and the necessary actions, for example, to cease the causes of the problems, to initiate the impeachment and the institution must send a written notice to the healthcare administrative agency.

At the same time, the ÁNTSZ is authorised to initiate a process ex officio in connection with the professional supervision of healthcare services. In this case, the examination is done according to the rules of the CL Act of 2016 (hereafter: Ákr.) and a mandatory decision is born with the possibility to impose a healthcare fine. Unfortunately, this examination is not possible in connection with individual complaints. If we examine the two proceedings, according to the law, the order of the Complaint Act has a secondary nature; its proceedings can be done if the complaints are not under the scope of another process, for example, an administrative proceeding. In practice, in the case of individual complaints, adjustment procedure is done automatically and, after that, if it is reasonable, the official administrative procedure is done, too. 
J Udit ZÁKÁNY, ALTERNATIVE POSSIBILITIES OF LEGAL PROTECTION AND ENFORCING CLAIMS IN THE AREA OF HEALTHCARE SERVICES IN HUNGARY

In our opinion, this is not necessary. The possibility of complaints to the healthcare government body would become a more efficient instrument for legal protection if, during the examination, an obligatory decision would be made, which would be a subject of a legal remedy and not just a notice. It can be possible if there would be a chance to do the process of the Ákr. in the case of individual complaints, and to make an obligatory decision, and if it is necessary to impose fine. As the Health Insurance Commission had had the authority to examine, impose a fine in cases of individual complaints. The professional supervision ex officio is completed, appropriately, with the individual complaints, they can show problems which make the act of the healthcare government body necessary. The suggestion is in connection with the practice because in decisions which impose healthcare fees, we can find references to prior adjustment procedure, so individual complaints have started the examination by the Ákr. and imposing the fee.

\subsection{The Office of the Commissioner for Fundamental Rights}

When the professional rules are not observed, this causes damage for thepatient so thereis an infringement. In Hungary, in this case, thecommissioner is not an alternative solution during the legal claiming, because he cannot examinemedical-professional questions, and cannot suggest paying ompensation. There is infringement too when the right to dignity is harmed during the treatment. This kind of infringement can establish to enforce the claim for nonmaterial damages on the litigious way, but in these cases, the commissioner can be an alternative solution ${ }^{37}$.

The Ombudsman deals with regularly the problems in connection with the enforcement and ability for enforcement of therights of the patients, through complaints or ex officio. In 2011-2012 this subject was a seeded examined area of the commissioner for fundamental rights.

The CXI Act of 2011 (hereafter: Ajbt.) has therules on the commissioner for fundamental rights. It begins with his competence. It is elemental that complaints must be reported against the right authority. The competence is based on the (1) Subject of 18. § in the Ajbt. which classes these institutions as institutions providing public services ${ }^{38}$. 
J Udit ZÁKÁNY, ALTERNATIVE POSSIBILITIES OF LEGAL PROTECTION

AND ENFORCING CLAIMS IN THE AREA OF HEALTHCARE SERVICES IN HUNGARY

To determine the competence, it is necessary that the activity or the negligence of the authority breaches a main right of the petitioner or causes a direct danger to the breach. The Fundamental Law (the Constitution of Hungary) appraises the right of health and the obligation to organise the Health Service, but the rights of patients are specified by the Health Act. The competence of the commissioner to examine the complaints in connection with the infringement of these rights is based generally on the fact that these rights come from the right of dignity, which is written in the Fundamental Law, and it is a basic right ${ }^{39}$.

A further condition of the examination is that the complainant was already used over the possibilities of administrative legal redress - except the judicial supervision of the administrative order - or that there were not any other ways. Even if the competence exists, it is not sure that the investigation can be conducted, because in some cases the petition can be refused without investigation ${ }^{40}$. During the investigation, the Ombudsman has different rights. For example, he can ask for an explanation from the examined institution, ask for the copy of the documents, ask the supervisory agency of the examined authority to investigate and perform field-monitoring ${ }^{41}$.

If the infringement of a fundamental right or a direct danger to the infringement is ascertainable than the commissioner for fundamental rights has several options. He does not have regulatory powers, he does not make compulsorily decision, he cannot determine a fine, but he has the power to make commendation to the concerned authority or its supervisor to solve the problem. On the performance of the commendation, the concerned part must inform him within 30 days. If there is not the necessary action, or the commissioner for fundamental rights does not agree with the action, he puts the case to the Parliament in the annual report, and he can ask the Parliament to investigate $i^{42}$.

According to the reports of the Ombudsman - on the health care complaints - there is an annual feature that the number of the complaints when the competence does not exist, is very high ${ }^{43}$. This proves that there is a great need for an investigation by the Ombudsman. The cause of the high rejection of the complaints is that the Ombudsman has very narrow competence in healthcare questions ${ }^{44}$, as we mentioned before, and the personal conditions does not exist neither in number, nor in qualification to deal with more complaints. 
J udit ZÁKÁNY, ALTERNATIVE POSSIBILITIES OF LEGAL PROTECTION AND ENFORCING CLAIMS IN THE AREA OF HEALTHCARE SERVICES IN HUNGARY

During examining the example from the other countries, we have seen independent institutions, unalike the Ombudsman, dealing with healthcare in New Zealand and the United Kingdom, which have broader authority and larger staff than in Hungary. Both in Hungary and in the examined countries, the Ombudsman has not got definitive, official rights, so it has a complementary role in the system of legal protection. His/ her role is to find the problems of the system according to the examinations based on the complaints and investigations ex officio, and to invite the organisations to solve them. The complement legal protection is different, however. If an independent Ombudsman is dealing with healthcare, the corresponding legal protection is more significant. We emphasise on the United Kingdom where there is an alternative solution to avoid disputed processes. Although there are many problems in connection with the Ombudsman in Hungary, in our opinion, after creating the institution of an Ombudsman - dealing with healthcare complaints - there has to be more significant results. The number of the complaints, the extent of the problems makes it so that is reasonable, in the present system, for at least one substitute to help the Ombudsman.

\section{Alternative compensation ways \\ 3.1 The process of the mediator}

There are two models of the mediation. First, there is the arbitration model, during which the arbitrator - chosen by the parties - makes (mainly) the final decision ${ }^{45}$ in the disputed case. Because the parties relinquish their right of decision and convey it to the arbitrator, this technique does not be long to the arbitrations ${ }^{46}$, but it is quite similar to the juridical way. However, the arbitrator is not a specialised judge, so he has pervasive discretionary powers, and he must solve the conflict between the parties respecting the principle of neutrality and impartiality. The arbitral tribunals, which are specialised in conflicts in connection with the healthcare services, can be found in the United States of America and Germany. In the United States of America there are the pre-trial screening panels ${ }^{47}$. The most important task of these bodies is to filter out the malicious processes, and if it is possible, to close the cases with agreements, and if it is not possible, to prepare for the judicial way. The number of the members are from three to seven. The panel usually consists of a judge, and one or more physicians specialised on the subject which is the object of the dispute ${ }^{48}$. 
J udit ZÁKÁNY, ALTERNATIVE POSSIBILITIES OF LEGAL PROTECTION

AND ENFORCING CLAIMS IN THE AREA OF HEALTHCARE SERVICES IN HUNGARY

In Germany, the medical chamber operates institutions which are process similar to the arbitration, but are not wholly the same, because the decision is not compulsory for the parties. The German Medical Chamber operates authorities, professional authorities and mixed authorities, which make settlements. The territorial medical chambers initiated their settings. The bodies decide the disputed questions between the doctors and the patients, and they can decide the legality of the claim and/ or the amount of the compensation. Theprofessional bodies givea professional opinion in connection with that the service which was performed to the patient was on the right level, or not ${ }^{49}$. Voluntarily working is the base of the process, and it is a free possibility for the patients, themedical chamber pays thecosts from the payment of the hospitals 50 .

The second model is the mediator model. This is based on cooperation, it is peaceful, and a mediator helps the parties to create a settlement. His task is to control the process of handling problems, so he does not judge, does not evaluate, does not decide the dispute. His role is to approach the sides and to revise the relationship between the parties ${ }^{51}$.

The Hungarian Health Act orders that the parties must initiate together the mediation to solve the dispute - between the patient and the healthcare supplier - out of court ${ }^{52}$. The Health Act rules thealternative ways. However, it does not determine that it must bethemediation or thearbitration model. The CXVI Act of 2000 on the mediator's process (hereafter: Közvtv.) answered the question with promoting the mediation in Hungary ${ }^{53}$. The detailed rules are in the 4/ 2001-es EüM-IM Decree.

During the mediation in connection with the healthcare disputes, voluntariness is the base. So, the process can only be conducted if the patient and the healthcare supplier participate ${ }^{54}$. Any party can be initiate the process. Nevertheless, the professional confidentiality is another essential principle and every party in the process must respect it ${ }^{55}$. This is a massive advantage against the judicial process because that is - with some exceptions public and the press is always interested. Another advantage of mediation is the fact that it does not cause conflict between the doctor and the patient or does not raise it. The aim is to prevent the conflict, to find common ground from which everyone will win. The proper communication, the proper information, taking the personal responsibility, paying respect to the interest of 
J udit ZÁKÁNY, ALTERNATIVE POSSIBILITIES OF LEGAL PROTECTION AND ENFORCING CLAIMS INTHE AREA OF HEALTHCARE SERVICES IN HUNGARY

the other party and the mutual compromise is necessary for the agreement, the mediators ensure these are assured mainly during this process. In the case of a conflict, the former ones would be the most important to the patient, as the research ${ }^{56}$ mentioned before, clearly shows.

The healthcare supplier and the representative inform the patient of the possibility and the terms of the mediation. The petition must be reported to the competent chamber of judicial experts. The chamber sends the petition to the other party who must declare if he contributes to the mediation. If every party agrees, after covering the costs, they must decide the content of the health mediation council ${ }^{57}$. They appoint the members of the council from the register of the Hungarian J udicial Professional Chamber (MISZK).

The first hearing of the healthcare mediation council must be made at the very latest on the 30th day after the agreement on the mediators. If the parties cannot agree, in 4 months after the first meeting, the process will be terminated. If the mediation is successful and the agreement was settled, then it becomes written, and the parties and the members of the council will sign it. If the party does not perform the agreement during the period of performance, the other party can ask the court to put an enforcement clause to the agreement. In this case, the agreement is enforceable according to the LIII Act of $1994^{58}$.

Even if we believe that it is good that in Hungary there is a mediator system on the healthcare, but it is unfortunate to admit that this form does not work, it did not make good ${ }^{59}$. One of the reasons is the lack of information both for the patients and the public, so there is not appropriate trust in it. The conduct of the healthcare service providers that they shift responsibility, and that they are not interested in nor the public knowledge of this solution, nor to search mistakes constantly - these facts are negative, too. It is our opinion the fact that this possibility is not free of charge, represents a problem, too. The costs can be around 100.000 Ft. The liability insurance companies do not prefer the out-of-court settlements, and agreements are compulsory to them, only if they had participated. However, some procedural rules are against the success of the healthcare mediation too, so their correction is essential for the mediation to become a well-known, active form of handling conflicts. We will express our proposal in the following chapter. 
J Udit ZÁKÁNY, ALTERNATIVE POSSIBILITIES OF LEGAL PROTECTION

AND ENFORCING CLAIMS IN THE AREA OF HEALTHCARE SERVICES IN HUNGARY

\subsection{The process of the conciliator body}

The conciliator bodies have been formed to solve the consumers' disputes out of court, operating as independent institutions next to the county and the capital Commercial and Trade Chambers, and these consists of a president, vice-president and members. These bodies are very effective and popular ways of enforcing a claim, because they are quick, cheap, based on collation and aim to make an agreement, in their processes a decision will be born even in the case of inefficiency, and it is compulsory. These procedures are available in connection with the healthcare services from May of 200460. The data of the reports of the conciliator bodies show that the process in connection with the healthcare services is sporadic, if there is one, it is usually in contact with the medical aids 61 . Because the features of the processes of the conciliator bodies do not concern our topic very much, we enhance the positive rules of the process which are proper to reform the mediation in the healthcare area.

The competence of the conciliator bodies covers the disputes between the consumer and the enterprises, in connection with the quality and the safe of the goods and services, product liability, signing a contract, and performing the contract. In the case of the healthcare services - according to the practice - the patient is a consumer if he has paid directly for the healthcare service. If the OEP is financially providing for the service, there is not consumer contract - according to the practice of the conciliator bodies ${ }^{62}$. If the healthcare institution operates as a budgetary agency, it acts as an economic organisation in the mirror of its civil legal connections, so in this way, the conciliator bodies have competence above them ${ }^{63}$.

Before initiating the process, the party must try to relate with the concerned economic organisation. The process can be started only by one of the parties: the social organisation, which represent the consumer or the interests of the consumers, and it can be initiated with a written petition to the president of the body. The other difference is that, in the case of mediation, the process can only be performed if the other party agrees, so if both of the parties accept this form. In the case of the procedure of the conciliator body, if the authorised party initiates the process, the body will decide, the other party's permission is not required. 
J Udit ZÁKÁNY, ALTERNATIVE POSSIBILITIES OF LEGAL PROTECTION AND ENFORCING CLAIMS INTHE AREA OF HEALTHCARE SERVICES IN HUNGARY

After examining the competence and the jurisdiction, the president decides about the date of the hearing and sends a notice about it. The conciliatory body works as a council with three members ${ }^{64}$, one of them is nominated by the consumer, the other by the enterprise from the list of the members of the conciliatory body. They choose the president. It is necessary that at least one of the members has a legal qualification, but I assume that a member with healthcare qualification is needed, too. The first aim of the process of the conciliator body is to make an agreement which suits the rules. In this case the council ratifies it, and the decision is compulsory. The process ends with a decision even if the parties cannot agree. This is an advantageous feature according to the mediation. In this case, the operating council decides either the rejection 65 of the consumers' petition, either to make compulsory decree or proposal - if the petitioner wins the dispute- it depends on that the economic organisation has or has not accepted the compulsory feature of the decision. If the enterprise does not perform the agreement and the compulsory decree, the consumer can ask to put an enforcement clause to the decree. In the case of a proposal, themalpractice of the economic organization has its consequences too, the conciliatory body can publish the essence of the dispute and the result 66 .

The process of the conciliator body has many positive features, which can be applied during the mediation, to increase its effectiveness. One of this opinion's reasons is that it makes sure to solve conflicts and get compensation in an out of court way. Naturally, this is the advantageous side of the out of court way. So, the process is much quicker because the rules order deadlines to perform the procedure. However - in contrast to mediation - the decision is given quickly, and its feature is based on the declaration of the enterprise. Along with the time efficiency, the lack of costs is essential too. We think this optional feature is a substantial positive fact, in contrast with the charges of the mediation. Moreover, it is important that the aim of the process is to solve theconflict with collation, to examine the problem reassuringly for the consumer, and to solve it appropriately for both parties. The consultation happens many times, because this is not just the aim of the process, but it is the premise of the institution of the process that the consumer must try to solve the case with the enterprise. But, the mutual agreement on initiating and performing the process is not necessary. We consider that the rules of the conciliator body are 
J Udit ZÁKÁNY, ALTERNATIVE POSSIBILITIES OF LEGAL PROTECTION

AND ENFORCING CLAIMS IN THE AREA OF HEALTHCARE SERVICES IN HUNGARY

more beneficial, because the consensus - which is required in the case of mediation - often disconcerts the possibility of solving the dispute.

\section{Final thoughts}

In connection with the legal options in the case of conflicts, injuries, damages in connection with health care services the main problem in Hungary is, in our opinion, that the classic form for disputes and enforcing claims predominates the alternative ways out of all proportion, and the latter ones are rarely applied. We think that one of the main reasons is that the system of the alternative methods of legal protection is complicated, the possibilities are not known appropriately. Rationalization an integration of possibilities is needed to make the system to be more comfortable to survey.

We have seen many functioning problems. Because of these, forms of compensation and handling conflicts do not operate according to the will of the legislator, nor the aims and the mechanisms in the rules. Problems in connection with the efficiency are against the use of these alternative ways. Our suggestions were reviewed in connection with the legal institutions.

The main principle during reforming the system is that the disputes must be solved on the lowest proper level. For this, a system needs, in which - beside the classic enforcing of a claim - there are alternative ways at different levels insuring legal protection, ending disputes and compensations.

If we investigate the alternative ways of handling conflicts, the main points must be the representatives. The base is a system consists of educated representatives of the rights of the patients with enough number, as we have seen it in connection with the Austrian system while examining the activity of the PA. If we want an efficient, popular alternative system, the number of the representatives of the rights of the patients must become the first forum. Examining the claims, in connection with the character of the complaints, they would suggest the most suitable out-of-court forum and help the claim.

In the system, an efficient investigation mechanism of complaints, which creates an internal control, is needed. Healthcare institutions must see that it is their interest to solve internal problems by the internal control mechanism and fewer conflicts would exist out of the institutions. However, for this real efficiency of the investigation of a complaint is needed and not 
J udit ZÁKÁNY, ALTERNATIVE POSSIBILITIES OF LEGAL PROTECTION AND ENFORCING CLAIMS INTHE AREA OF HEALTHCARE SERVICES IN HUNGARY

just the formal performance. We think that institutional investigation of a complaint is better than the complaint about the operator, because circumstances can bebetter examined, peoplecan belistened, compared with thesituation when the operator can work only by his documents. Based on the researches, the efficient institutional investigation of a complaint improves the quality of services.

Between the mechanisms of the legal protection, there must be an organisation with official authority, which examines ex officio and according to the complaints of the patients, gives binding decisions, and has the power to impose fees. The Health Insurance Commission has operated this way, and at present the Public Health Organizations of the Government Offices does this. We do not think that the discrimination of the individual complaint and the investigation ex officio is necessary because there has not been any discrimination in the proceeding of the Health Insurance Commission. An organisation with official authority improves the quality of services too in connection with the enforcement of the binding decisions and the disputes.

Besides these, a healthcare commissioner is needed as an additional legal protector. In countries which have Ombudsman's dealing with healthcare complaints, this additional legal protection institution is very popular and efficient.

In our opinion, a conciliation way for compensation would beenough, but basic modifications are needed in connection with the procedure and more popularity is necessary, too. In the case of mediation, the healthcare disputes have not already been under the scope of the general order, while only the financial consumer legal disputes are privileged from the general rules of the conciliation hearing. In our opinion, the best solution will be if the healthcare mediation would be the base, and some provisions of the conciliation hearing would correct it.

1 This study was written within the framework of the OTKA PD_16 postdoctoral application. (120901 ÁJ P has been implemented with the support provided from the National Research, Development and Innovation Fund of Hungary, financed under the PD_16 funding scheme.).

* Research fellow of Civil Procedure Department at the University of Debrecen, Faculty of Law, Hungary.

${ }^{2}$ For example, the most important need for the injured party to get answers. The aim of the evidentiary procedure of the civil suit must be this, but in our opinion, this does not materialise in every case. Considering the actual juridical practice, in many cases, the technical 
elements of the evidentiary procedure determine the end of the cases, instead of the real problem. To find answers to causes, the patient must file charges, which is not essential. The alternative ways are possible solutions, I suppose furthermore, that these deal with solving the real problem and revealing the facts preferably.

${ }^{3}$ We mean avoiding the problems (for instance, with improving resources, revising the system of the terms and tools) and avoid conflicts (for example with better communication).

${ }^{4}$ If there is a conflict, how and with which instrument can it be solved?

${ }^{5}$ With the data of the Health Insurance Control.

${ }^{6}$ LESTER, Gregory W. - SMITH, Susan G., Listening and Talking to Patients, The Western J ournal of Medicine, 1993, March, 270-271.

${ }^{7}$ HaIMAN Éva, Az érzelmekben fürdő emlékezet (interjú), J ogorvoslap, 2009, 6. szám, 4.

${ }^{8}$ Naturally, the importance of the compensation depends on the person's situation and depends on the level on which the social system of the country gives financial help to the injured party. For example, in Hungary the child who was born injured because of genetic, teratological cause, cannot claim financial compensation on his own right because of the fact that her mother has not been informed or not well by the doctors during the pregnancycare, so she has not been able to use her right for abortion which is guaranteed by the law. But, the country is liable for helping the impaired people. (1/2008 PJ E VI.).

${ }^{9}$ Dr. Protál honlapja: http:/ / www.drportal.hu/ hir.php?szid=99\&tema=27\&hid=3579 (downloaded: 13J anuary 2012).

10 Meruelo, Natasha C., Mediation and Medical Malpractice, The J ournal of Legal Medicine, 2008, Vol. 29., Iss. 3, 290.

${ }^{11}$ For making groups for the possibilities of legal protection I have seen other stands, for example when there are the ones in the healthcare suppliers, and the other ones which are organized by a third party. (Lásd: KERESZTY Éva: Csalódottság vagy kár? Gondolatok az egészségügyi ellátási károk rendezéséről, In: J UHÁSz Zoltán (ed.): Kárfelelősség és a reparáció lehetséges eszközei, Az alapvető jogok biztosa és a MABISZ konferencia-kiadványa, Budapest, 2013, 30.).

12 It is impossible to write all the rights in this paper, so I just mention the rights from the Health Act: right for the healthcare service, right for human dignity, the right for communication, right for leaving the institution, the right for information, right for autonoour, right for refusal the service, right for knowing the documents, right for the professional secrecy. (To see the detailed examination of the rights of the patients, see for example: SÁNDORJ udit, A betegek jogainak kodifikálásáról, Fundamentum, 1997/ 1., 87-100.).

13 KőszEgFalvi Edit, Egészségügyi jogi kézikönyv, Közgazdasági és J ogi Könyvkiadó, Budapest, 1999, 90.

14 During our own consultation with a representative I have realized that the patients usually do not know the independence (from the hospitals) of the representatives, so there were many cases when the patients feared that his complaint would influence negatively his further treatment.

${ }^{15}$ Health Act 32. § (2) Subsection. 
Judit ZÁKÁNY, ALTERNATIVE POSSIBILITIES OF LEGAL PROTECTION AND ENFORCING CLAIMS INTHE AREA OF HEALTHCARE SERVICES IN HUNGARY

${ }^{16}$ Health Act 32. § (1) Subsection (The Integrated Legal Protection Service is the independent part of the ministry, led by the minister who is responsible for the healthcare, social and pension policy and the protection of children and youth. 381/2016 (XII. 2.) Korm. rendelet).

${ }^{17}$ NAGY András László, Egy éves a jogvédelmi központ, IME, 2013/9., 10.

18 Health Act 33. § (1) Subsection.

${ }^{19}$ Health Act 30. § (2) Subsection Point a).

20 POLECSÁK Mária (ed.), A betegekjogai, Vince Kiadó, Budapest, 1999, 55.

${ }^{21}$ It is important that the representative, usually, does not have the right to represent the patient. There is an exception, when he represents the psychiatric patients, for example during the out-of-court proceeding review of the necessity of the institutional medication. Lásd: KôszEGFALVI Edit, Egészségügyi és betegjogi kézikönyv, KJ K Kerszöv, Budapest, 2001, 105.

22 SÁRINÉ SimKó Ágnes - HídvÉGINÉ ADORJÁN Lívia: Orvos- beteg jogviszonyok az egészségügyben I. A betegek jogairól, Medicina, Budapest, 2012, 174.

23 There are more factors which encumber the activity of the representatives, for example, the lack of sources, or the different attitude from the institutions to the work of the representatives. Lásd: ANTAL Géza, Egy aktív magyar betegjogi képviselő vallomása, Comitatus, 2007, november-december, 100-109.

${ }^{24}$ HEUER Orsolya (ed.), Betegjogok Magyarországon- Szabályok és gyakorlat, TASZ, Budapest, 2002, 27.

25 MACKENNEY, Stephen - FALLBERG, Lars (eds.): Protecting Patients Rights? A Comparative Study of the Ombudsman in Health Care, United Kingdom, Radcliff Medical Press Ltd., 2004, 14

${ }^{26}$ LUKÁCS József - FóNYAD László, Az intézményi kármegelőzés (risk management) és a minőségbiztosítás, Egészségügyi Gazdasági Szemle, 1998/6., 590.

27 214/ 2012 (VII. 30.) Korm. rendelet 19. § (2) c) point has disposed of this.

${ }^{28}$ For more, read: NÁDHÁZY Zsolt- ZÁKÁNY J udit: Az intézményi panaszkezelés új iránya: a klinikai mediátor, Med et J ur, 2014/2., 14-17.

29 Ehi. 6. § (1) Section b) Point.

30 KovÁCSY Zsombor - DósA Ágnes (eds.): A vállalkozó orvosok nagy kézikönyve, Complex, Budapest, 2011, 709.

${ }^{31}$ Based on the Ehi. 14/C. §.

32 The complaint is a petition, which aims the cessation of the breach of an individual right or interest and its settling does not belong to the scope of other - specifically judicial or administrative - process. (Complaint Act 1 . § (2) Section.).

33 The public announcement draws attention to a circumstance, in connection with it its remedy, or its cessation serves the interest of the society. (Complaint Act 1 . § (3) Section).

34 According to the 96/ 2003 (VII. 15.) Government Regulation 7. § (2) Section, the complaint can be tendered to the National Public Health and Medical Officer Service or the public health institution of the districts, it depends on that which institution is the subject of the complaint/ public announcement.

35 33/ 2013. (V. 10.) EMMI rendelet 4. § (1) Section.

36 KOVÁCSY - DÓSA i.m. 708.

${ }^{37}$ Except when the compensation for non-material damages is the first aim. 
J Udit ZÁKÁNY, ALTERNATIVE POSSIBILITIES OF LEGAL PROTECTION AND ENFORCING CLAIMS IN THE AREA OF HEALTHCARE SERVICES IN HUNGARY

${ }^{38}$ Beszámoló az állampolgárijogok országgyúlési biztosának 2009. évi tevékenységéről, Országgyúlési Biztos Hivatala 2010, 80.

39 BoRZA Beáta (ed.), AJ B Projektfüzetek, Beteg jogaink-egészség és méltóság, Betegjogi Projekt 2012, 14.

40 20th Section of CXI Act of 2011

41 21-22th Section of CXI Act of 2011.

42 Further possibilities, for example:

The commissioner for fundamental rights - to remedy the thwarting in connection with the fundamental right - can initiate the action of the prosecutor, through the public prosecutor. (1st Subsection of the 33th Section of CXI Act of 2011).

The commissioner for fundamental rights can turn to the Constitutional Court, based on the Act on the Constitutional Court. (34 Section of CXI Act of 2011).

If the commissioner for fundamental rights - during his investigation - thinks that there is substantial suspicion of committing a crime, he can initiate criminal procedure at the institution which has competence. (1st Subsection of the 35th Section of CXI Act of 2011).

43 See for example: Beszámoló az állampolgári jogok országgyúlési biztosának 2009. évi tevékenységéről, Országgyưlési Biztos Hivatala 2010, 113.

${ }^{44}$ Beszámoló az állampolgári jogok országgyúlési biztosának 2010. évi tevékenységéről, Országgyülési Biztos Hivatala 2011, 81.

45 The decision must be enforced if the parties have written a submission statement, if it lacks, the enforcement can be refused.

${ }^{46}$ NÁDHÁZY Zsolt, A döntőbíráskodás magyarországi aspektusai, Munkaügyi Szemle, 2005, 11. szám, 51.

47SÁRINÉ SiMKÓ Ágnes (ed.), A mediáció, HVG ORAC, Budapest, 2006, 210.

48SÁRINÉ [2006] i.m. 211.

${ }^{49}$ Nys, Herman, The Factual Situation of Medical Liability in the Member States of the Council of Europe, In: The Ever Growing Challenges of Medical Liability: National and European Responses, Strasbourg, 2-3J une 2008, 21.

50 StAUCH, Marc S.: Medical Malpractice and Compensation in Germany, Chicago Kent Law Review, 2011, Vol. 86, Iss. 3, 1161.

${ }^{51}$ NÁDHÁZY Zsolt, Alternatív vitafeloldás Európában - különös tekintettel a munkaügyi vitákra, J ogtudományi Közlöny, 2007, 7-8. szám, 315.

52 Health Act 34. §.

53 In Hungary, the LXXXI Act of 1994 on arbitration does not let this form to be supplied in connection with conflicts on healthcare services. According to the rules of this Act, the judicial process can only be allowed if - at least - one of the parties deals with economic activity business likely and the dispute is in connection with this activity, and if the parties can decide about the subject of the process free, and if the arbitration has been written in their contract (3. § (1) Subject). Because the healthcare service is not a commerce/ economical activity, in these disputes the arbitration is not allowed.

54 EÖRSI Mátyás - ÁBRAHÁM Zita (eds.): Pereskedni rossz!, Minerva Kiadó, Budapest, 2003, 164.

${ }^{55}$ DósA Ágnes: Az orvos kártérítési felelőssége, HVG ORAC, Budapest, 2004, 43. 
J udit ZÁKÁNY, ALTERNATIVE POSSIBILITIES OF LEGAL PROTECTION AND ENFORCING CLAIMS IN THE AREA OF HEALTHCARE SERVICES IN HUNGARY

${ }^{56}$ LESTER, Gregory W. - SMith, Susan G., Listening and Talking to Patients, The Western J ournal of Medicine, 1993, March, 270-271.

${ }^{57}$ Közvtv. 3.§.

58 SárINÉ Simkó Ágnes (ed.): A mediáció, HVG ORAC, Budapest, 2006, 225.

59 Because there is no data on the mediation processes, the causes of the inefficiency, or efficiency, so there are not exact data in connection with the litigations to back our statements. The data of the public research from the Decastello Alice give us information to the 20002006 term on the low number of the mediation processes. Under this term - nationwide 182 mediation processes were initiated in connection with healthcare disputes. The major part of these have not even begun, because the healthcare supplier or the insurance institutions didn't contribute to the process, or the patient receded. In the investigated term mediation in only 12 cases was successful. ${ }^{59}$ During our consultation with our representative, we optained the information that unfortunately mediation is very rarely applied. The repre sentative has seen only one instance when it was solved during mediation.

60 Simon Tamás, Emészthetóek-e a fogyasztói jogok az egészségügyben, avagy a be tegtájékoztatás jelenéról,

http:// www.384ugyvediiroda.hu/index.php/ cikkek-tanulmanyok/ dr-simon-tamas-irasai.html (downloaded: 30 May 2013).

${ }^{61}$ See: the page if the conciliator bodies: $\mathrm{S}$ https:/ / bekeltetes.hu/index.php?id=szakmai-beszamolo-es-elemzes-a-bekelteto-testuletek-2009-evi-tevekenysegerol (downloaded: 12 December 2013).

${ }^{62}$ According to the consultation with the president of the conciliator body, in accordance with

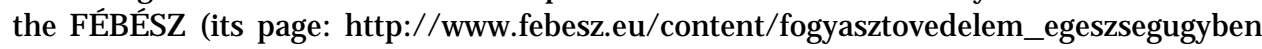
(downloaded: 9 April 2014.).

63 Pp. 396. §.

${ }^{64}$ If the consumer's dispute is uncomplicated, a member with legal qualification can perform it. (4th Subsection of the 25th Section of CLV. Act of 1997).

65 Fvtv. 32/A. §.

${ }^{66}$ ÁBRAHÁM Edit, Békéltető testületek: a fogyasztói jogviták rendezésének alternatív fórumai, In: SÁRINÉ SimKó Ágnes (ed.), Mediáció - Közvetítói eljárások, HVG ORAC, Budapest, 2012, 301. 